\title{
MODEL PEMBINAAN KEAGAMAAN DI ASRAMA BINA SISWA SMA PLUS CISARUA PROVINSI JAWA BARAT
}

\author{
Abdurrohman Yusup* dan Edi Suresman \\ Universitas Pendidikan Indonesia, Bandung \\ *E-mail: abdurrochmanyusup@gmail.com
}

\begin{abstract}
This research was motivated by the important role of dormitory that wasable to produce the students with many achievements, but there still haveproblems, such as: dating, bulying, and stealing. The purpose of this research is to find out the model of religious guidance at Bina SiswaDormitrory SMA PlusCisarua West Java. This research was conducted with qualitative approach and descriptive case study design. Data collection was done by interview technique, observation, dandocumentation study. The results of this research are: (1) Religious guidance program is divided into two agenda namely daily and weekly activities, (2) The implementation of religious guidance includes the practice of praying congregation, tadarus al-Quran, student lecture, tahajud prayer, mubadhoroh (speech), mubadasab(conversation),tausiyah, guidance of worship, fasting on Monday and Thursday, tahsin, memorizing al-Quran and etc, (3) The religious guidance can increasethe understanding and implementation of religious confidence of the students, and can decline the level of serious violation of students.
\end{abstract}

Keywords: Model, Religious Guidance, Dormitory, Student

\begin{abstract}
ABSTRAK
Penelitian ini dilatarbelakangi oleh peran asrama yang mampu menghasilkean siswa-siswi unggul dan berprestasi, namun di sisi lain masib ditemukan kasus penyimpangan siswa, misalnya berpacaran, bulying, danmencuri. Penelitian ini bertujuan untuk mengetahui model pembinaan keagamaan di Asrama Bina Siwa SMA Plus Cisarua Provinsi Jawa Barat. Penelitian ini dilakukan dengan pendekatan kualitatif dengan desain studi kasus. Pengumpulan data dilakukan dengan teknik wawancara, observasi, studi dokumentasi. Penelitian berkesimpulan babwa: (1) Pembinaan keagamaan ini mengadopsi sistem kepesantrenan, dengan program kegiatan harian dan mingguan, serta program ekstrakulikuler keagamaan, (2) Pelaksanaan pembinaan keagamaan ini antara lain: shalat berjama'ah, tadarus Al-Qur'an, kultum siswa, shalat tahajud, muhadhoroh (pidato), mubadatsah (percakapan), tausiyah, bimbingan ibadah, puasa Senin-Kamis, tabsin, dan hafalan qur an, (3) Pembinaan keagamaan tersebut dapat membantu meningkatkan pemahaman dan pengamalan keagamaan siswa, serta menurunkan tingkat pelanggaran berat siswa.
\end{abstract}

Kata Kunci :Model, Pembinaan Keagamaan, Asrama, Siswa

TARBAWY: Indonesian Journal of Islamic Education - Vol. 5 No. 2 (2018) | 186 


\section{PENDAHULUAN}

Pendidikan mempunyai peranan penting dalam menjamin perkembangan serta kelangsungan hidup suatu negara. Sebagaimana yang termaktub dalam Pembukaan UUD 1945 bahwasanya mencerdasakan kehidupan bangsa merupakan salah satu tujuan dari kemerdekaan Indonesia. Kehidupan bangsa yang cerdas hanya mampu terwujud melalui pendidikan, sebab pencerdasan merupakan fungsi dari pendidikan. Dengan pendidikan diarahkan mampu memahamkan kesadaran manusia akan kemandirian dalam menata masa depannya dan untuk menanamkan nilai-nilai kehidupan yang baik dalam diri peserta didik (Fakhruddin, 2014). Pendidikan nasional disusun sebagai usaha sadar untuk memungkinan pertahanan akan keberlangsungan hidup serta pengembangan diri masyarakat Indonesia secara berkelanjutan.

Dalam UUD 1945 pasal 28 C, ayat 1) dinyatakan bahwa :

"Setiap orang berhak mengembangkan diri melalui pemenuhan kebutuhan dasarnya berhak mendapatkan pendidikan dan memperoleh manfaat dari IPTEK (ilmu pengetahuan dan teknologi), seni dan budaya demi meningkatkan kualitas hidup dan demi kesejahteraan umat manusia."

Jika ketentuan UUD 1945 dicermati maka pendidikan merupakan hak asasi bagi setiap warga Indonesia. Dan sebuah kewajiban sebagai warganegara untuk ikut serta dalam upaya pendidikan yang diselenggarakan oleh pemerintah guna mencerdaskan dan menyejahterakan kehidupan bangsa.

Program pengembangan Sumber Daya Manusia merupakan salah satu prioritas perhatian pembangunan baik dalam lingkup nasional, maupun regional Provinsi Jawa Barat. Sejalan dengan perkembangan zaman yang tengah berada dalam dinamika pembangunan yang cukup pesat, dengan berbagai ancaman yang mengarah pada lunturnya karakter di kalangan pelajar (Firmansyah, 2017), maka pendidikan formal sebagai bagian terpadu dari program pengembangan Sumber Daya Manusia perlu mendapatkan pengembangan inovatif agar sesuai dengan tuntutantuntutan kehidupan di masa yang akan datang.

Pemerintah Provinsi Jawa Barat melalui Dinas Pendidikan Provinsi Jawa Barat memberikan kesempatan program gratis melanjutkan pendidikan sekolah menengah atas (SMA). Adapun persyaratannya, lulus SMP/MTs yang merupakan siswa/siswi berprestasi dan berpotensi, berasal dari keluarga yang perlu dibantu baik yatim piatu, yatim, piatu, dan keluarga lengkap. Siswa-siswi yang diterima akan dididik dengan sistem pembinaan yang mengutamakan kedisiplinan berlandaskan nilai-nilai agama (program kepesantrenan), serta budaya tanpa biaya hidup, dan selama tiga tahun harus tinggal di Asrama Bina Siswa.

Asrama Bina Siswa didirikan pada tahun 1995 berdasarkan Surat

TARBAWY: Indonesian Journal of Islamic Education - Vol. 5, No. 2 (2018) | 187 
Keputusan Gubernur Jawa Barat. Pada prinsipnya berisikan program pendidikan SMA secara umum dilengkapi dengan program-program tambahan yang berorientasi pada dunia aplikasi kerja, serta melengkapi wawasan siswa/siswi untuk menghadapi tantangan kehidupan dengan harapan dapat mencetak lulusan SMA yang unggul, siap pakai serta memiliki nilai plus, berkompetensi, berjiwa kewirausahaan, berbudi luhur, bermoral dan bertakwa kepada Tuhan Yang Maha Esa.

Asrama merupakan tipe pendidikan yang sangat disiplin dengan aturan yang ketat. Tidak ada waktu yang terbuang percuma tanpa belajar, bekerja, dan berdo'a. Sistem pendidikan seperti ini bertujuan menghasilkan lulusan yang penuh dengan kedisiplinan dalam hidup sehingga bisa menjadi pribadi yang unggul dalam bidang yang digelutinya (Dawan, 2012).

Sutrisnodalam (Hendriyenti 2014, hlm. 208) mengungkapkan terdapat beberapa keunggulan dari sekolah berasrama (boarding school) antaranya lain:

a. Program pendidikan paripurna

Umumnya sekolah-sekolah regular terkonsentrasi pada kegiatan-kegiatan akademis sehingga banyak aspek hidup anak yang tidak tersentuh. Hal ini terjadi karena keterbatasan waktu yang ada dalam pegelolaan program pendidikan pada sekolah regular. Sebaliknya, sekolah berasrama dapat merancang program pendidikan yang komprehensif holistik dari program pedidikan keamanan, perkembangan akade-mik, keahlian hidup sampai membawa wawasan global. Bahkan pembelajaran tidak hanya sampai pada tataran teoritis, tapi juga implementasi baik dalam konteks belajar ilmu ataupun belajar hidup.

b. Fasilitas lengkap

Sekolah berasrama mempunyai fasilitas yang lengkap, mulai dari fasilitas ruang belajar, fasilitas kesehatan, ruang asrama sampai ruang dapur.

c. Guru yang berkualitas

Sekolah-sekolah berasrama umumnya menentukan persyaratan kualitas guru yang lebih jika dibandingkan dengan sekolah konvensional. Kecerdasan intelektual, sosial, spiritual, dan kemampuan peadagogis-metodologis serta adanya jiwa kependidikan pada setiap guru. Ditambah kemampuan bahasa asing, seperti bahasa Inggris, Arab, dan Mandarin.

d. Lingkungan yang kondusif

Dalam sekolah berasrama semua elemen yang ada dalam kompleks sekolah terlibat dalam proses pendidikan. Begitu juga dalam membangun sosial keagamaannya, maka semua elemen yang terlibat mengimplementasikan agama secara baik.

TARBAWY: Indonesian Journal of Islamic Education - Vol. 5, No. 2 (2018) | 188 
e. Siswa yang heterogen

Sekolah berasrama mampu menampung siswa dari berbagai latar belakang yang tingkat heterogenitasnya tinggi. Berasal dari berbagai daerah dengan latar belakang sosial, budaya, tingkat kecerdasan, kemampuan akademik yang sangat beragam. Kondisi ini sangat kondusif untuk membangun wawasan nasional dan siswa terbiasa berinteraksi dengan teman-temannya yang berbeda sehingga sangat baik bagi anak untuk melatih wisdom anak dan menghargai pluralitas.

f. Jaminan keamanan

Jaminan keamanan diberikan boarding school, mulai dari jaminan kesehatan, tidak narkoba, terhindar dari pergaulan bebas, dan jaminan keamanan fisik (tawuran dan perpeloncoan), serta pengaruh kejahatan dunia maya.

g. Jaminan kualitas

Dalam sekolah berasrama, pintar tidak pintarnya anak, baik dan tidak baiknya anak sangat tergantung pada sekolah karena 24 jam anak berasrama sekolah. Sekolah-sekolah dapat melakukan treatment individual, sehingga setiap siswa dapat melejitkan bakat dan potensi individunya. Sedangkan di sekolah konvensional jika anak pintar harus dibantu oleh lembaga bimbingan belajar dan lainlain.

Dalam meminimalisir penyimpangan siswa, Asrama Bina Siswa memiliki program pembinaan keagamaan dengan sistem pembelajaran kepesantrenan yang diharapkan bukan saja menghasilkan lulusan SMA yang unggul dalam intelektualnya juga kepribadian luhur serta akhlak yang mulia.

Pembinaan diartikan sebagai upaya memelihara atau membawa suatu keadaan yang seharusnya terjadi. Dapat dikatakan juga bahwa pembinaan keagamaan merupakan bagian dari pendidikan yang mempunyai arah untuk mendayagunakan semua sumber sesuai dengan rencana dalam rangkaian kegiatan keagamaan untuk mencapai tujuan yang telah ditetapkan. Ketercapaian tujuan pendidikan itu sendiri dimanifestasikan dalam perubahan pribadi siswa dengan segala aspeknya (Fakhruddin, 2012)

Pembinaan dapat dilakukan melalui dua fungsi pendekatan, yaitu pendekatan langsung dan pendekatan tidak langsung (Sudjana, 2010, hlm. 218).

Asrama pendidikan secara manajerial dipandang sebagai sebuah sistem yang terdiri atas beberapa elemen penting, yaitu perencanaan, pengorganisasian, pelaksanaan, pengawasan dan pembiayaan. Asrama pendidikan akan dapat mendukung pencapaian tujuan lembaga secara keseluruhan jika dikelola secara baik, efektif dan efisien. Efektifitas dan

TARBAWY: Indonesian Journal of Islamic Education - Vol. 5, No. 2 (2018) | 189 
efisiensi pengelolaan asrama pendidikan, pada umumnya dipengaruhi oleh faktor internal dan eksternal. Kedua faktor ini harus ada, saling mendukung dan melengkapi dalam pengelolaan atau manajemen asrama (Munir, 2016, hlm. 288).

Beberapa fungsi manajemen di antaranya:

a. Perencanaan dan Pengorganisasian Perencanaan merupakan salah satu aspek penting dalam sebuah menejemen pembinaan, hal ini dibuat dengan usaha dalam rangka mencapai suatu tujuan. Karena seringkali pelaksanaan kegiatan akan mengalami kesulitan dalam mencapai tujuan tanpa adanya perencanaan (Wibowo, 2013, hlm. 139). Sedangkan pengorganisasian adalah proses menentukan hubungan-hubungan yang esensial di antara orang-orang, tugas-tugas, aktivitas-aktivitas, dengan cara mengintegrasikan dan mengkoordinasikan semua sumber orgaisasi ke arah pencapaian suatu tujuan secara efektif dan efesien (Marno \& Supriyatna, 2008, hlm.16)

b. Pelaksanaan

Pelaksanaan merupakan fungsi manajemen yang sifatnya komplek serta ruang lingkupnya cukup luas juga berhubungan dengan sumber daya manusia. Penggerakan merupakan salah satu fungsi terpenting dalam manajemen. Pentingnya pelaksanaan penggera- kan didasarkan pada alasan bahwa, usaha-usaha perencanaan dan pengorganisasian bersifat vital tapi tak akan ada output kongkrit yang dihasilkan tanpa adanya implementasi aktivitas yang diusahakan dan diorganisasikan dalam suatu tindakan usaha yang menimbulkan aksi (Marno \& Supriyatna, 2008, hlm. 20).

c. Pengawasan

Pengawasan adalah usaha memberi bimbingan, saran, perintah, atau instruksi kepada bawahan dalam melaksanakan tugas masing-masing, agar tugas dapat dilaksanakan dengan baik dan benar-benar tertuju pada tujuan yang telah ditetapkan. Pengarahan berfungsi bukan saja agar pegawai melaksanakan atau tidak melaksanakan suatu kegaiatan, tetapi juga berfungsi mengkoordinasikan kegiatan, agar efektif tertuju kepada realisasi tujuan yang tetapkan (Wibowo, 2013, hlm. 151).

d. Evaluasi

Evaluasi merupakan teknik penilain terhadap tingkah laku peserta didik berdasarkan standar perhitungan yang bersifat komperhansif dari seluruh aspek kehidupan mentalpsikologis dan spiritual-religius (Umar, 2010, hlm. 195).

Secara realitas pelaksanaan sekolah berasrama dalam pembinaan karakter siswa yang dijalankan oleh Asrama Bina bukanlah perkara mudah, karena mereka yang dididik adalah

TARBAWY: Indonesian Journal of Islamic Education - Vol. 5, No. 2 (2018) $\mid 190$ 
siswa-siswi yang berasal dari berbagai daerah dengan latar belakang serta status keluarga yang berbeda-beda. Bahkan kenakalan remaja masih kerap terjadi. Hal inilah yang menjadi kendala yang dihadapi pihak pendidik dan penyelenggara asrama.

\section{METODE PENELITIAN}

Desain penelitian merupakan gambaran umum penelitian yang akan dilaksanakan peneliti untuk mencapai tujuan tertentu. Desain penelitian ini ialah implikasi dari kompleksitas hubungan antara variabel penelitian melalui usaha pengumpulan data dan analisis data untuk mendapatkan temuan sebagaimana tujuan dan proses penelitian yang telah dipilih (Indrawan \& Yaniawati, 2014, hlm. 30). Desain yang digunakan dalam penelitian ini adalah case study atau studi kasus. Studi kasus merupakan bentuk penelitian yang mendalam tentang suatu aspek lingkungan sosial termasuk manusia di dalamnya.

Adapun pendekatan penelitian yang digunakan peneliti adalah pendekatan kualitatif. Dimana dalam pendekatan kualitatif ini data hasil penelitian lebih berkenaan dengan interprestasi terhadap data yang telah ditemukan di lapangan. Selain itu dalam pendekatan kualitatif ini, peneliti sebagai instrumen kunci, dan teknik pengumpulan data yang dilakukan dengan trianggulasi (Sugiyono, 2013, hlm.15).
Partisipan penelitian merupakan orang-orang yang berpartisispasi atau terlibat langsung dalam penelitian. Adapun partisipan dalam penelitian ini di antaranya ialah Kepala Asrama, Koordinator Kesiswaan, Petugas Bina Mental Spiritual Putera dan Puteri, serta Peserta Didik Asrama Bina Siswa. Penelitian dilakukan di Asrama Bina Siswa SMA Plus Cisarua Provinsi Jawa Barat yang berlokasi di Jl. Terusan Kolonel Masturi No. 64 Cisarua, Kabupaten Bandung Barat, Jawa Barat.

Teknik pengumpulan data merupakan cara-cara atau teknk-teknik tertentu yang digunakan dalam pengumpulan data. Penelitian harus menjelaskan dalam desain dan laporan hasil penelitiannya tentang cara-cara atau teknik-teknik yang digunakan dalam mengumpulkan data penelitiannya (Darwis, 2014, hlm. 56).

Penelitian ini bertujuan untuk mendapatkan data berupa model pembinaan keagamaan sebagai gambaran dari kegiatan-kegiatan pembinaan keagamaan di Asrama Bina Siswa SMA Plus Cisarua Provinsi Jawa Barat dengan memperhatikan proses pembinaan, peristiwa yang terjadi, serta autentisitas dari pembinaan keagamaan itu sendiri. Selanjutnya bila dilihat dari segi cara, maka teknik pengumpulan data dapat dilakukan dengan cara observasi (pengamatan), teknik wawancara serta studi dokumentasi atau gabungan dari ketiganya atau trianggulasi. 
Adapun penelitian ini menggunakan ketiga teknik tersebut, dengan teknik observasi digunakan untuk melihat model pembinaan keagamaan di Asrama Bina Siswa. Selanjutnya teknik wawancara peneliti gunakan sebagai satu teknik untuk mengetahui secara lebih mendalam mengenai perencanaan, pelaksanaan serta evaluasi dan hasil yang didapatkan dalam program pembinaan keagamaan. Kemudian teknik studi dokumentasi dimana peneliti mengumpulkan data serta dokumentasi yang mendukung dalam penelitian yang berkaitan dengan pembinaan keagamaan di asrama tersebut.

Di akhir, peneliti menggunakan triangulasi sumber untuk menguji keabsahan data yang didapatkan di lapangan. Triangulasi sumber berarti membandingkan dan mengecek kembali kepercayaan suatu informasi yang diperoleh melalui waktu dan alat yang berbeda dalam penelitian kualitatif (Moleong, 2014, hlm. 330-331).

Peneliti melakukan trianggulasi sumber dengan cara membandingkan data dokumen dengan data hasil pengamatan, membandingkan data hasil pengamatan dengan hasil wawancara, dan membandingkan keadaan dan perspektif para informan agar menghasilkan data yang valid serta reliabilitas.

\section{HASIL PENELITIAN DAN}

PEMBAHASAN

\section{Perencanaan Pembinaan Ke-} agamaan di Asrama Bina Siswa

Kegiatan perencanaan selalu terkait dengan masa depan. Tanpa perencanaan, sekolah atau lembaga pendidikan akan kehilangan kesempatan dan tidak dapat menjawab pertanyaan tentang apa yang akan dicapai, dan bagaimana pencapaiannya. Oleh karena itu perencanaan perlu dibuat agar semua tindakan terarah pada tujuan yang hendak dicapai (Marno \& Supriyatna, 2008, hlm. 13).

Perencanaan pembinaan keagamaan merupakan bagian daripada perencanaan kegiatan kesiswaan Asrama Bina Siswa SMA Plus Cisarua. Koordinator kesiswaan sebagai unsur terpenting dalam pelaksanaan organisasi memiliki tanggung jawab untuk merencanakan kegaiatan pada setiap semesternya dalam mencapai sasaran yang dituju. Ruang lingkup perencanaan pembinaan keagamaan mencakup penetapan sumber dana, sumber daya organisasi, dan perencanaan pelaksanaan program satu semester kedepan. Setiap awal semester selalu diselenggarakan rapat mengenai targetan kurikulum, pembagian tugas bidang kesiswaan, penetapan wali asuh, jadwal kegiatan kepesantrenan, pembagian tugas piket

TARBAWY: Indonesian Journal of Islamic Education - Vol. 5, No. 2 (2018) | 192 
serta fungsinya, materi ajar, dan evaluasi program.

Menurut Sa'ud \& Syamsuddin (2009, hlm. 33) perencanaan penting dilakukan dalam sebuah program dan organisasi, adapun pentingnya perencanaan ialah :

a. Dengan adanya perencanaan diharapkan tumbuhnya suatu pengarahan kegiatan, adanya pedoman bagi pelaksanaan kegiatan-kegiatan yang ditujukan kepada pencapaian tujuan.

b. Dengan perencanaan, maka dapat dilakukan suatu perkiraan terhadap hal-hal dalam masa pelaksanaan yang akan dilalui. Perencanaan mengusahakan supaya ketidakpastian dapat dibatasi sedini mungkin.

c. Perencanaan memberikan kesempatan untuk memilih alternatif tentang cara terbaik atau kesempatan memilih kombinasi cara terbaik.

d. Dengan perencanaan dilakukan penyususnan skala prioritas. Memilih urutan-urutan dari segi pentingnya suatu tujuan, sasaran, maupun kegiatan usahanya.

e. Dengan adanya rencana, maka akan ada suatu alat pengukur atau standar untuk mengadakan pengawasan atau evaluasi kinerja usaha atau organisasi.

Untuk sumber biaya program pembinaan, sebenarnya sudah di- anggarkan oleh pemerintah. Pihak asrama diberikan kewenangan dalam melaksanakan program-program yang telah direncanakan. Namun sebenarnya untuk pembinaan keagamaan sendiri tidak banyak mengeluarkan biaya.

Termasuk pemilihan pembina dan pengajar asrama direncanakan dengan mengutamakan yang memiliki latar belakang pendidikan agama dan pengalaman yang didahulukan, serta memiliki jiwa yang selalu membantu, mampu mendorong, memberi motivasi terhadap siswa-siswa yang menjadi tanggung jawab. Karena pembinaan keagamaan di Asrama Bina Siswa lebih mendorong pada motivasi.

Perencanaan pembinaan keagamaan merupakan bagian daripada perencanaan kegiatan kesiswaan Asrama Bina Siswa SMA Plus Cisarua. Koordinator kesiswaan sebagai unsur terpenting dalam pelaksanaan organisasi memiliki tanggung jawab dalam merencanakan kegaiatan pada setiap semesternya untuk mencapai sasaran yang dituju. Perencanaan dilakukan pada setiap awal semester dengan agenda rapat mengenai targetan kurikulum, penetapan wali asuh, jadwal, materi, program serta prosedur yang harus dilakukan selama satu semester.

\subsection{Pelaksanaan Pembinaan Keaga- maan di Asrama Bina Siswa}

TARBAWY: Indonesian Journal of Islamic Education - Vol. 5, No. 2 (2018) $\mid 193$ 
Pelaksanaan merupakan fungsi manajemen yang sifatnya komplek serta ruang lingkupnya cukup luas juga berhubungan dengan sumber daya manusia. Penggerakan merupakan salah satu fungsi terpenting dalam manajemen. Pentingnya pelaksanaan penggerakan didasarkan pada alasan bahwa, usaha-usaha perencanaan dan pengorganisasian bersifat vital tapi tak akan ada output kongkrit yang dihasilkan tanpa adanya implementasi aktivitas yang diusahakan dan diorganisasikan dalam suatu tindakan usaha yang menimbulkan aksi (Marno \& Supriyatna, 2008, hlm. 20).

Pelaksanaan pembinaan keagamaan (kepesantrenan) yang dilakukan Asrama Bina Siswa SMA Plus Cisarua Provinsi Jawa Barat pada prosesnya terdapat dua program yaitu program harian dan program mingguan, dengan fokus pelaksanaan setelah salat subuh dan salat magrib.

Metode yang dilakukan dalam pelaksanaan pembinaan keagamaan untuk kegiatan harian banyak menggunakan metode tajribi atau mempraktikan langsung ibadah. Sedangkan untuk kegiatan tausiyah menggunakan metode ceramah. Selebihnya menggunakan metode diskusi, dialog, kisah qur'ani dan sebagainya. Adapun program tersebut, diuraikan sebagai berikut:

\section{a. Kegiatan Harian}

Analisis peneliti dalam program pembinaan keagamaan dari kegiatan harian adalah pola pembiasaan siswa untuk melaksanakan ibadah dengan latihan-latihan ibadah yang sifatnya terjadwal. Sudah tentu upaya ini memberikan arahan terhadap siswa, selama tinggal di asrama tidak lepas dari belajar, ibadah dan berusaha. Tidak ada waktu yang terbuang percuma selain dari ketiga hal tersebut. Dari kegiatan harian ini menggunakan metode tajribi atau pelaksanaan langsung. Terdapat lima kegiatan antara lain:

- Salat Berjama'ah

Pembiasaan salat berjama'ah dilakukan oleh seluruh siswa Asrama Bina Siswa. Untuk pelaksanaannya pada setiap sholat maghrib, isya dan subuh, adapun dzuhur dan asar dikembalikan pada sisiwa karena saat itu siswa sedang sekolah reguler. Salat berjama'ah dilakukan agar siswa mampu membiasakan siswa salat tepat pada awal waktu.

- Tadarus Al-Qur`an

Tadarus Al-Qur`an merupakan kegiatan membaca Al-Qur’an sesuai dengan keinginan atau target ayat yang ingin dibaca. Adapun pelaksanaan tadarus yang dilakukan seluruh siswa Asrama Bina Siswa biasanya ketika sebelum belajar di meja belajar, waktu mandiri siswa di

TARBAWY: Indonesian Journal of Islamic Education - Vol. 5, No. 2 (2018) | 194 
tempat yang dikehendaki baik di mesjid ketika menunggu adzan.

- Kultum Siswa

Pelaksanaan kultum ini dilakukan setelah salat subuh di Masjid Baitul Muta'allimin secara terjadwal oleh siswa kelas X dan XI, sedangkan siswa putri dilaksanakan di Mes. Kegiatan ini bertujuan dalam melatih siswa mampu berbicara di depan umum. Jika dalam suatu waktu siswa belum siap untuk melaksanakan kultum, biasanya diganti dengan siswa yang sudah siap kultum, dan siswa yang belum siap tadi dijadwalkan kembali esok harinya. Selain itu juga sesekali kegiatan kultum ini dilaksanakan oleh pembina.

- Salat Tahajud

Kegiatan Qiyamul lail atau salat tahajud dilakukan oleh seluruh siswa Asrama Bina Siswa setelah mereka dibangunkan oleh pembina sekitar pukul 03.30, tempat pelaksanaan di masjid bagi siswa dan di mes bagi putri. Setelah salat tahajud biasanya siswa membaca Al-Qur`an atau bertadarus. Hal ini dilakukan agar siswa mampu membiasakan sunnahsunnah nabi saw. sesuai dengan firman Allah Swt.

\section{b. Kegiatan Mingguan}

- Muhadharah (Pidato)

Kegiatan muhadharah merupa-kan kegiatan pidato yang dilakukan oleh kelompok muhadharah. Pelaksanakan dilakukan setiap minggu malam dengan pengawasan OPA. Rangkaian kegiatan di antaranya penyampaian tausyiah, tilawah, dan do'a dari kelompok mihadhoroh.

- Muhadashah (Percakapan)

Kegiatan ini dilaksanakan setiap senin setelah salat subuh dengan materi percakapan bahasa baik bahasa arab atau inggris. Pemberian materi bahasa arab dimulai dengan tasrifan. Dilanjut dengan percakapan bahasa arab yang dipaparkan dilakukan berulang oleh siswa. Sedangkan materi bahasa inggris dimulai dengan pengenalan kosa kata baru, dilanjut dengan percakapan bahasa inggris.

\section{- Tausiyah Umum}

Tausiyah umum dilakukan oleh seluruh siswa Asrama Bina Siswa di Masjid Baitul Muta'alimin, setiap senin malam setelah salat magrib. Pemberian tausiyah ini bersifat umum biasanya pembina memberikan tausiyah dengan materi berbeda setiap minggunya, sesuai yang direncanakan baik Al-Qur an dan hadist, aqidah, akhlak, sejarah, atau hikmah kehidupan.

TARBAWY: Indonesian Journal of Islamic Education - Vol. 5, No. 2 (2018) $\mid 195$ 
- Diskusi 'Am (Umum)

Kegiatan diskusi 'am dilakukan oleh seluruh siswa Asrama Bina Siswa, untuk putra di masjid dan putri mes dengan pengawasan pembina, setiap rabu malam setelah salat magrib. Diskusi dilakukan dalam memecahkan sebuah masalah oleh kubu pro dan kontra dengan pengangkatan isu-isu hangat demi melatih siswa dalam berargumen.

\section{- Istigasab dan Yasinan Bersama}

Istigasah merupakan doa untuk memohon pertolongan kepada Allah Swt dengan membaca do'a-do'a khususdengan pembacaan surat yasin. Kegiatan ini dilakukan oleh seluruh siswa Asrama Bina Siswa di Masjid Baitul Muta'allimin, dilakukan setiap kamis malam setelah salat magrib. Yasinan dan istigasah dipimpin oleh bapa pembina. Kegiatan ini dilakukan dalam rangka berdo'a untuk diri sendiri, keluarga, asrama, pembina, dan agar dimudahkan dalam proses belajar mengajar.

- Taḥsin dan Hafalan Al-Qur`an

Begitupun kegiatan tạ̣sin dan hafalan Al-Qur`an yang dilakukan oleh Asrama Bina Siswa. Kegiatan ini dilakukan bersama-sama karena dalam menghasilkan hafalan yang baik perlu mengetahui bacaan yang benar. Pelaksanakan kegiatan tạ̣sin dan hafalan Al-Qur`an ini dilaksanakan setiap setelah salat maghrib setiap jumat malam dan setiap salat subuh pada hari rabu, kamis, dan sabtu dengan pengawasan pembina. Rangkaian kegiatan di antaranya taḥsin kelompok, hafalan kelompok, yang dipimpin oleh muddabirnya masing-masing dan penyetoran hasil kepada pembina.

- Puasa hari Senin dan Kamis

Anjuran puasa sunnah dilakukan oleh Asrama Bina Siswa dalam melatih siswa terbiasa hidup hemat susai dengan sunnah Rasūlullāh. Para siswa beserta pembina bersama-sama melaksanakan sahur dan berbuka puasa pada hari tersebut.

- Praktik Khutbah Jum'at

Kegiatan khutbah jum'at oleh siswa asrama kelas XII putra terlaksana secara bergantian terjadwal setiap hari jum'atnya. Diawali oleh pembina pada awal bulan dan selanjutnya oleh siswa. Kegiatan ini dilakukan agar siswa kelak siap menjadi agen dakwah di masyarakat.

\section{c. Kegiatan Ekstrakulikuler}

ProgramKatalis-Q merupakan kegiatan ekstrakulikuler keagamaan di Asrama Bina Siswa. Dibentuk pada tahun 2014 dengan tujuan sebagai wadah pengembangan intensif siswa asrama dalam meningkatkan kapasitas bacaan Al-Qur'an yang baik juga dalam meningkatkan hafalan $\mathrm{Al}$ -

TARBAWY: Indonesian Journal of Islamic Education - Vol. 5, No. 2 (2018) | 196 
Qur'an siswa yang punya keinginan lebih untuk menghafal.

\subsection{Evaluasi dan Hasil Pembinaan Keagamaan di Asrama Bina Siswa}

Evaluasi merupakan cara atau teknik penilain terhadap tingkah laku peserta didik berdasarkan standar perhitungan yang bersifat komprehensif dari seluruh aspek kehidupan mental-psikologis dan spiritualreligius karena manusia hasil pendidikan Islam bukan saja sosok pribadi yang tidak hanya bersikap religius, melainkan juga berilmu dan berketerampilan yang sanggup beramal dan berbakti kepada Tuhan dan masyarakatnya (Umar, 2010, hlm. 195).

Kegiatan evaluasi yang dilakukan dalam program pembinaan keagamaan dari segi kognitif untuk siswa ialah tes akhir dari materi kepesantrenan, juga praktik bimbingan ibadah yang telah menjadi targetan kurikulum. Hasil dari tes akhir materi dikalkulasikan dengan nilai praktik, kemudian dimasukan pada rapot asrama setiap siswanya dan tentunya hal ini sangat memudahkan siswa dalam memahami pelajaran PAI di sekolah.

Evaluasi program dilakukan untuk memperbaiki kegiatan pembinaan keagamaan baik berupa rancangan ulang tentang materi ajar (apakah ada penambahan atau pergantian materi), wali asuh, jadwal program kepesantrenan, juga targetan satu semester kedepan bagi siswa dengan pertimbangan faktor pendukung, dan penghambat dari program pembinaan keagamaan.

Dari hasil studi dokumentasi peneliti, program pembinaan keagamaan ini nampaknya membuahkan hasil yang baik. Bisa dilihat dari data pelanggaran di tahun ajaran terakhir 2016/2017 mengalami penurunan. Terlepas dari hal itu, pelanggaran yang dilakukan siswa masih bisa berubah sewaktu-waktu.

\section{KESIMPULAN}

Berdasarkan hasil penelitian yang telah diuraikan, tentu menjadi gambaran tersendiri bahwa program pembinaan keagamaan yang dilakukan Asrama Bina Siswa mampu mengarahkan siswa akan pentingnya hidup beragama.

Dengan pembiasaan dan praktikpraktik keagamaan mampu menghasilkan siswa dengan akhlak mulia yang tercermin dari awal peneitian. Siswa lebih banyak disibukan dengan kegiatan positif sehingga mengurangi dampak negatif dan penyimpangan remaja.

Namun pembinaan ini akan lebih baik lagi dengan ditingkatkan kembali SDM pengawasan terhadap setiap kegiatan siswa, agar benar-benar terawasi dengan baik oleh para pembina, guna mencegah sekecil apapun peyimpangan. 
Model Pembinaan Keagamaan di Asrama Bina Siswa SMA Plus Cisarua Provinsi Jawa Barat

\section{REFERENSI}

Darwis, A. (2014). Metode Penelitian Pendidikan Islam. Jakarta: PT Raja Grapindo Persada.

Dawan, Y. A. (2012, Juni 25). Sekolah Asrama, "Sekolab" Bulying dan Mencuri. Dipetik 1 12, 2017, dari http://m.kompasiana.com: http://m.kompasiana.com/yoha nes.a.d.fernandez/sekolahasrama-sekolah-bulying-danmencuri_550e12e33311ba7e94

Fakhruddin, A. (2014). Urgensi Pendidikan Nilai Untuk Memecahkan Problematika Nilai Dalam Konteks Pendidikan Persekolahan. Taklim: Jurnal Pendidikan Agama Islam, Vol. 12 No. 1.

Fakhruddin, A. (2012). Manajemen Ekstrakurikuler Keagamaan di Sekolah. Tesis.

Firmansyah, Mokh. I. (2017). Program Pembudayaan Terpadu dalam Membina Karakter Islami Siswa Sekolah Dasar Sebagai Implementasi Kurikulum "Bandung Masagi." , 1(2), pp. 91-97.

Hendriyenti. (2014). Pelaksanaan Program Boarding School Dalam Pembinaan Moral Siswa Di SMA Taruna Indonesia Palembang. Jurnal
Raden Fatab (Ta'dib), Vol. XIX, 24.

Indrawan, R., \& Yaniawati, P. (2014). Metodologi Penelitian. Bandung: Refika Aidtama.

Kebudayaan, S. J. (2016). Ikbtisar Data Pendidikan Tahun 2015/1016. Jakarta : Pusat data dan Statistik Pendidikan dan Kebudayaan.

Marno, \& Supriyatna, T. (2008). Manajemen Pendidikan Islam. Bandung: PT Refika Aditama.

Moleong, L. J. (2014). Metodologi Penelitian Kualitatif Edisi Revisi. Bandung: PT Remaja Rosdakarya.

Munir, M. (2016). Kultur Asrama Berbasis Sekolah sebagai Pusat Pembinaan Karakter SMPIT AlFurqan Palembang . Jurnal Raden Fatah (Intizar) , 282-296.

Sa'ud, U. S., \& Syamsuddin, A. (2009). Perencanaan Pendidikan. Bandung: PT Remaja Rosdakarya Offset.

Sudjana, D. (2010). Manajemen Program Pendidikan. Bandung: PT Remaja Rosdakarya.

Sugiyono. (2013). Metode Penelitian Kuantitatif dan Kualitatif dan RD. Bandung: Alfabeta.

Umar, B. (2010). Ilmu Pendidikan Islam. Jakarta: Amzah.

Wibowo, A. (2013). Manajemen Pendidikan Karakter di Sekolah. Yogyakarta: Pustaka Pelajar. 